\title{
The Effect of Debt to Asset Ratio and Debt to Equity Ratio Against Return on Assets
}

\author{
Deni Sunaryo ${ }^{1}$, Etty Puji Lestari ${ }^{2}$ \\ \{denisunaryomm@gmail.com ${ }^{1}$ \} \\ Student of the Terbuka University Management Science Doctoral Study Program and Lecturer at the \\ Faculty of Economics and Business, Serang Raya University, Banten Indonesia ${ }^{1}$ \\ Terbuka University, Indonesia ${ }^{2}$
}

\begin{abstract}
The purpose of this study is to ascertain the determinants of return on assets caused by the debt-to-asset and debt-to-equity ratios by analyzing the financial statements of food and beverage companies listed on the Southeast Asian Stock Exchange between 2012 and 2018. The independent variables (free) and dependent variables (dependent) are used in this study, with the dependent variable being the Debt to Asset and Debt to Equity Ratios, and the independent variable being the Return on Assets. Purposive sampling was used to identify eight companies that provided complete financial reports in order to obtain 56 samples. Multiple linear regression analysis, a partial test, and a simultaneous test were used in this study. The study's findings suggest that the Debt to Asset Ratio has a significant effect on Return on Assets, while the Debt to Equity Ratio does not. The results of the concurrent study of the Debt to Asset Ratio and the Debt-to-Equity Ratio on Return On Assets indicate that both have a significant effect on Return On Assets at a level of $0.200>0.05$, indicating that both the Debt to Asset Ratio and the Debt to Equity Ratio have a significant effect on Return On Assets.
\end{abstract}

Keywords: Debt to assets ratio, debt to equity ratio, return on assets

\section{Introduction}

There are numerous types of businesses in the business world, and each type of business has a sizable number of competitors or competitors, particularly those discussed in this journal, namely companies in the food and beverage sector. Because one of a human being's primary needs is to eat and drink. Therefore, the company that operates in the food and beverage sector is one company that has a fairly wide market share and can be said to be the main company in the world. With this, companies engaged in the food and beverage sector must be able to manage their finances well, so that the company can run stably. Both those in a stable state must be able to control in order to remain stable, and for companies that are in a state of decline, they must be able to control them so that they continue to increase in profit by reducing expenses and increasing their profits.

In this study, which will be used to calculate company expenses, namely the variable Debt to Asset Ratio which calculates the total debit divided by the company's total assets, the Debt to Equity Ratio which calculates the total debit divided by the total equity or what is called the company's capital and the Return On Assets which can calculate operating profit divided by the total assets owned by each company in accordance with the standards owned by each variable. Companies that have listed themselves on the stock exchange must issue a financial report every 
year containing the company's assets, including a profit report and dividend payment in accordance with the Decree of the Chairman of Bapepam Number KEP-51/P/1996 dated 17 January 1996 (BEJ) or which is in accordance with the stock exchange of each country. The issuance of financial reports has the objective of making external parties aware of the company's developments and prospects.

The profitability ratio is a ratio for evaluating the company's profitability. This ratio also measures the efficiency of a company's management. This is shown by the profit from sales and investment income. The point is that this ratio shows the company's efficiency (Switzerland, 2010: 196). The profitability ratios can be used by means of comparisons between the different components of the financial statements, particularly the financial balance sheet and the income statement. A number of operating periods can be measured. The purpose is to see the company's development decrease or increase within a certain time frame, as well as the causes of the company. The company should therefore be careful how to improve profits, but the most important thing is to ensure that its profit is maintained so that every year it increases [19].

There are several studies that have been done before and have produced various differences regarding the Debt-to-Asset and Debt-to-Equity Ratios in Relation to Return on Assets. A similar study was conducted by Pebrianti [12] who examined Debt to Assets Ratio, Debt to Equity Ratio, Long Term Debt to Equity Ratio, international ownership and managerial ownership have an effect on LQ45 company profitability. According to research by Widiyanti and Elfira [9] who examined Financial Leverage on Profitability, it was stated that the effect of Debt to Assets Ratio and Debt to Equity Ratio on return on assets was negative. According to Afrinda's research [11] on the effects of liquidity and solvency on profitability in Indonesia's bonded food and beverage companies (BEI), debt-to-asset ratio and the debt-to-equity ratio have negative but insignificant effects on returns. According to Kamal's research [7], which examined the effect of Receivable Turnover and Debt to Assets Ratio on Return on Assets for agricultural companies listed on the Indonesian Stock Exchange (BEI), Debt to Assets Ratio had no significant effect on Profitability Return On Assets.

The authors are concerned, on the basis of the above description, with the effect of the ratios of financial solvency on the profitability growth of sub-sector food and beverage companies listed on the South East Asian Börse for seven periods from 2012 to 2018. The title of this research is therefore "The Effect of Debt to Asset Ratio and Debt to Equity Ratio Against Return On Assets"

\section{Method}

According to Dukeshire and Thurlow in Sugiyono [15] states that research is a systematic way to collect data and present the results. The research method is defined as a scientific way of obtaining data for particular purposes and applications. There are four keywords that need to be considered, namely, scientific methods, data, purposes, and certain uses.

Quantitative data are the type of data used. According to Sugiyono [15], the quantitative method is called the traditional method, since this method has traditionally been used as a method of research for a long time. In the meantime, a secondary data source is the data source used by researchers. According to Sugiyono [15], secondary sources of information are sources that do not provide data directly to data collectors, such as other individuals or documents.

The research type used in this research is a quantitative method and the data source used is secondary data, which are designed to investigate the causality of research, namely a research 
design which examines the possibility of causal relationships between variables. In this sample collection, 8 companies in the food and beverage sub-sector in Southeast Asia were able to obtain samples that matched the criteria for the 7 periods 2012-2018 which presented complete financial reports so that 56 samples were generated.

Table 1. List of Food and Beverage Subsector Companies in Southeast Asia which were the Research Samples for the 2012 - 2018 Period

\begin{tabular}{|l|l|l|}
\hline State & Code & Coorporate \\
\hline \multirow{4}{*}{ Indonesia (BEI) } & ICBP & PT. Indofood CBP Sukses Makmur Tbk \\
\cline { 2 - 3 } & DLTA & PT. Delta Djakarta Tbk \\
\cline { 2 - 3 } & CEKA & PT. Jbilmaz Cahaya Indonesia Tbk \\
\hline \multirow{3}{*}{ Bursa Malaysia } & AINOMOTO & Ajinomoto Berhad Malaysia \\
\cline { 2 - 3 } & APOLLO & Apollo Food Holdings Berhad Malaysia \\
\cline { 2 - 3 } & NESTLE & Nestlé (Malaysia) Berhad Malaysia \\
\hline \multirow{2}{*}{$\begin{array}{l}\text { Singapore } \\
\text { Exchange (SGX) }\end{array}$} & DELFI & Petra Foods Limited Singapura (Delfi) \\
\cline { 2 - 3 } & INDOAGRI & Indofood Agri Resources Ltd \\
\hline
\end{tabular}

The dependent variable or dependent variable, the researcher uses a return-to-asset ratio, and a debt-to-asset ratio and a debt-to-equity ratio for the independent variable or independent variable. Multiple linear regression analysis, partial test and simultaneous tests are the analytical technique used.

\section{Results and Discussion}

\subsection{Descriptive statistics}

Table 2. Descriptive Statistics Test Results

Descriptive Statistics

\begin{tabular}{|c|c|c|c|c|c|c|c|c|c|}
\hline & $n$ & Range & Ninimum & Vacimum & Sum & \multicolumn{2}{|c|}{ Mean } & Std. Deviation & Variance \\
\hline & Statstic & Stafstc & Stabisti: & Statisf: & Stafsfic & Statist: & St. Enor & Statsfic & Stafisfic \\
\hline DAR & 56 & 59.90 & .10 & 60.00 & 458.45 & $8.18 \% 5$ & 1.92334 & 14.39297 & 207.158 \\
\hline DER & 56 & 85.98 & .12 & 85.10 & 1586.09 & 28.3230 & 4.28472 & 3205389 & 1028093 \\
\hline ROA & 56 & 7.74 & .10 & 7.84 & 59.71 & 1.0663 & .20209 & 1.51230 & 2287 \\
\hline Valid N (listwise) & 56 & & & & & & & & \\
\hline
\end{tabular}

Based on table 2, an explanation of the results of descriptive statistical testing is described as follows:

\subsubsection{Debt to asset ratio (DAR)}

In this descriptive statistical data processing, it is aimed at the results with the number of valid data as many as 56, Delta Djakarta Tbk. Indonesia in 2017 and a maximum of 60.00 owned by PT. Petra Foods Limited Singapore (Delfi) was in the year 2012 with an average or average value of 8,1866 , a standard deviance value of 14,39297, and an adjusted value of 207,158. 


\subsubsection{Debt to equity ratio (DER)}

In 2017 the debt to equity ratio variable is a minimum of 0,12 that is owned of PT. Delta Djakarta Tbk. Indonesia and a maximum of 86,10 that belongs to PT. Indofood CBP Sukses Makmur Tbk, Indonesia in 2013, a median or average of 28,3230, standard deviation of 32,06389 and a variance of 1028,093, Indofood CBP.

\subsubsection{Return on assets (ROA)}

And the asset ratio data has a minimum of 0,10 in 2018 owned by Apollo Food Holdings Berhad Malaysia and a maximum of 7,74 owned by PT. In 2014, the average or averaged value of Petra Foods Limited Singapshop (Delfi) is 1,0663.

\subsection{Classic assumption test}

\subsubsection{Normality test}

Table 3. Normality Test Results - Kolmogorov-Smirnov Test

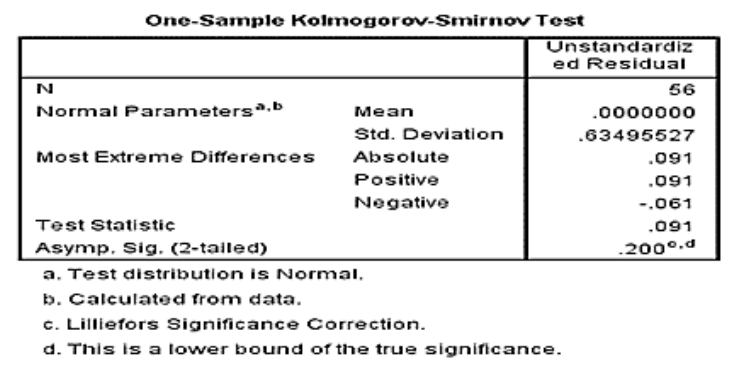

Based on Table 3, the results of the following normality test show that with a sample size of 56 the normality test results show that the value of the Kolmogorov-Smirnov is satisfied, or that the remaining data has been distributed, referring to the result of the Kolmogorov trial with asymp sig 2 tailed above $0.05(0.200>0.05)$. The following is a Figure 1 depicting the results of the normality test.

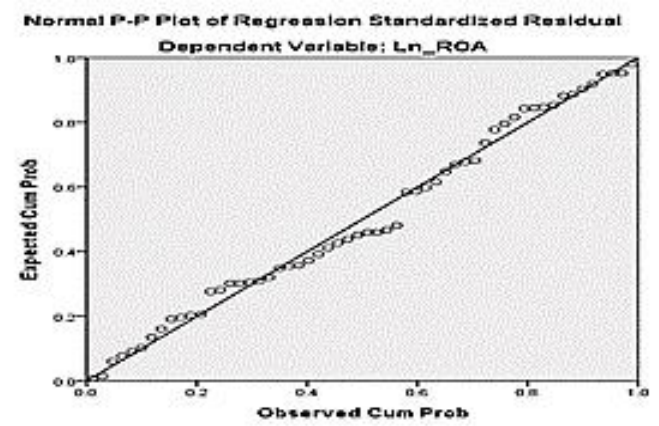

Fig. 1. Data Normality Test Results 
The results of the normality test show that the points spread around the diagonal line and follow the diagonal line direction, so that the regression model meets normality requirements. In this study the normality test uses the Kolmogorov Smirnov Test. This test is used for statistical tests whether the data is normally or is not distributed. Kolmogorov-Smirnov Test the rules, i.e. if the resulting value $>0.05$ is the normal distribution data. Conversely, if the resulting value is $<0.05$, the data is normally not distributed.

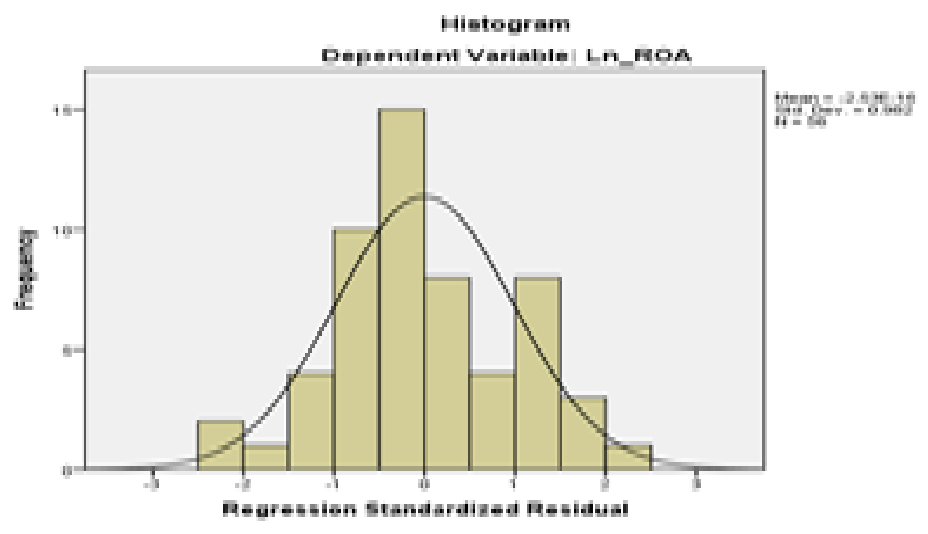

Fig. 2. Data Normality Test Results

Based on the results of the above-mentioned graph test, it shows that the normality test is performed as shown in the diagonal diagram.

\subsubsection{Autocorrelation test}

Table 4. Autocorrelation Test Results

Model Summary
\begin{tabular}{|l|c|r|r|r|r|}
\hline Model & $R$ & R Square & $\begin{array}{c}\text { Adjusted R } \\
\text { Square }\end{array}$ & $\begin{array}{c}\text { Sid. Error of } \\
\text { the Estimate }\end{array}$ & $\begin{array}{c}\text { Durbin- } \\
\text { Watson }\end{array}$ \\
\hline 1 & $.706^{\text {a }}$ & .499 & .479 & .62521 & 2.012 \\
\hline
\end{tabular}
a. Predictors: (Constant), lag_DER, lag_DAR
b. DependentVariable: lag_ROA

On the basis of Table 4, the SPSS autocorrelation test results show a Durbin-Watson (DW) 2.012 value, indicating that DW is between DU (1.64295) to 4-DU (2.35705). There is therefore no positive or negative autocorrelation in the area of the critical value observation sample from Durbin-Watson. 


\subsubsection{Heteroscedasticity test}

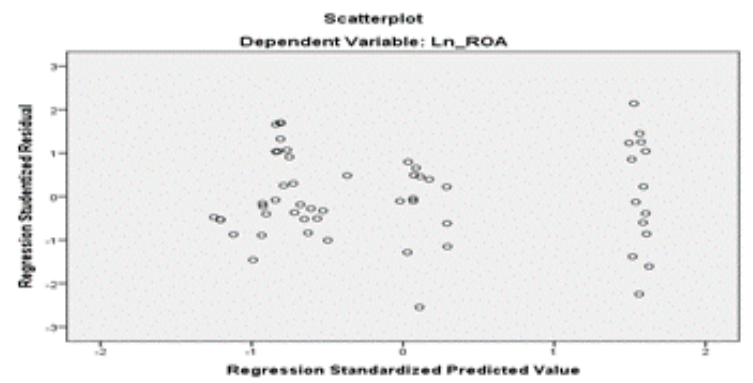

Fig. 3. Heteroscedasticity Test Results

Figure 2, showing the results of the heteroscedasticity test, the residual data in both regression models show that the results have spread below and above the number 0 and do not form a pattern. There are therefore no symptoms of heteroscedasticity in the regression model proposed in this study.

\subsubsection{Multicollinearity test}

Table 5. Multicollinearity Test Results

\begin{tabular}{|c|c|c|c|c|c|c|c|c|}
\hline \multicolumn{9}{|c|}{ Coefficients $^{\mathrm{a}}$} \\
\hline \multirow[b]{2}{*}{ Model } & & \multicolumn{2}{|c|}{ Unstandardzed Coefficients } & \multirow{2}{*}{$\begin{array}{c}\text { Standardized } \\
\text { Coefficients } \\
\text { beta }\end{array}$} & \multirow[b]{2}{*}{$t$} & \multirow[b]{2}{*}{ Sig. } & \multicolumn{2}{|c|}{ Collineantit/Statistics } \\
\hline & & $B$ & Std. Error & & & & Tolerance & MF \\
\hline \multirow[t]{3}{*}{1} & (Constant) & -.705 & .111 & & -6.354 & .000 & & \\
\hline & Ln_DAR & .259 & .054 & .529 & 4.827 & .000 & .576 & 1.737 \\
\hline & LI_DER & .140 & .045 & .343 & 3.128 & .003 & .576 & 1.737 \\
\hline
\end{tabular}

On the basis of Table 5, all independent variables, namely the debt ratio, and the debt-toequity ratio, can be seen to be met during the multi-linearity test because each variable has a tolerance value of less than 0.10 and a VIF of less than $<10$. This means that the data are not multi-linear, so that they are useful in the regression model.

\subsection{Model accuracy test}

\subsubsection{Simultaneous significance test (Test F)}

Table 6. F Test Results

ANOVA $^{\mathrm{a}}$

\begin{tabular}{|ll|r|r|r|r|c|}
\hline Model & & \multicolumn{1}{|c|}{$\begin{array}{c}\text { Sum of } \\
\text { Squares }\end{array}$} & \multicolumn{1}{c|}{ df } & Mean Square & $\mathrm{F}$ & Sig. \\
\hline 1 & Regression & 38.331 & 2 & 19.166 & 45.809 & $.000^{\mathrm{b}}$ \\
& Residual & 22.174 & 53 & .418 & & \\
& Total & 60.505 & 55 & & & \\
\hline
\end{tabular}

a. Dependent Variable: Ln_ROA

b. Predictors: (Constant), Ln_DER, Ln_DAR 
The results of the F test show that the F value calculated exceeds the F Table value, 45.809> 3.17 and its meaning is less than $0.05(0.000<0.05)$. This means that all $\mathrm{X}$ variables affect the Y variable simultaneously.

\subsection{The coefficient of determination (R2)}

Table 7. Results coefficient of determination (R2)

\begin{tabular}{l|c|c|c|c|}
\hline Model & R & R Square & $\begin{array}{c}\text { Adjusted R } \\
\text { Square }\end{array}$ & $\begin{array}{c}\text { Std. Error of } \\
\text { the Estimate }\end{array}$ \\
\hline 1 & $.796^{\mathrm{a}}$ & .634 & .620 & .64682 \\
\hline
\end{tabular}
a. Predictors: (Constant), Ln_DER, Ln_DAR
b. Dependent Variable: Ln_ROA

From the above table, the Adjusted R2 value reflects the ability of the independent variables to explain the variance in the adjusted variable. Based on processing using SPSS 23 Windows software, it is found that the adjusted R2 value is the value of R2 which indicates that the Y variable is influenced by all $\mathrm{X}$ variables by $63.4 \%$, the remaining $36.6 \%$ is influenced by other variables outside of this study.

\subsection{Multiple linear regression analysis}

Table 8. Results of Multiple Linear Regression Analysis

\begin{tabular}{|c|c|c|c|c|c|c|}
\hline & & \multicolumn{5}{|c|}{ Coefficients $^{\mathrm{a}}$} \\
\hline \multirow[b]{2}{*}{ Model } & & \multicolumn{2}{|c|}{ Unstandardized Coefficients } & \multirow{2}{*}{$\begin{array}{c}\text { Standardized } \\
\text { Coefficients } \\
\text { Beta }\end{array}$} & \multirow[b]{2}{*}{$\mathrm{t}$} & \multirow[b]{2}{*}{ Sig. } \\
\hline & & $B$ & Std. Error & & & \\
\hline \multirow[t]{3}{*}{1} & (Constant) & -.705 & .111 & & -6.354 & .000 \\
\hline & Ln_DAR & .259 & .054 & .529 & 4.827 & .000 \\
\hline & Ln_DER & .140 & .045 & .343 & 3.128 & .003 \\
\hline
\end{tabular}

Multiple regression uses data in the unstandardized coefficient column B. Judging from the results of the multiple linear analysis test above, it can be explained that the multiple linear regression analysis model is as follows:

$$
\mathrm{ROA}=-0,701+0,259 \mathrm{Ln} \mathrm{DAR}+0,140+, 0,140 \mathrm{LnDER}
$$

The linear regression equation above shows that, (1) a constant producing the number 0.705 , i.e. if the debt to equity and the indebtedness to equity ratio equals $(0)$, the return on equity ratio is -0.705 . The results of this linear regression test show that a decrease in the value of Return on Assets results in a value not complying with the standard. (2) $\beta 1$ or Debt to Asset Ratio producing 0.259 that shows that Return on Asset has a positive effect and will rise by 0.259 . The results of the above-mentioned linear regression analysis can also be interpreted to suggest that the value of the Debt to Asset Ratio increases and goes beyond the standard compared to the decreasing results of the Return on Asset test. This contributes to the positive effect of the variable X1 on variable Y, which can be caused by default (default), given that the company finances too much debt assets. (3) $\beta 2$ or Equity Debt Ratio produces a value that continues to rise over several periods outside standard, leading to the 0.140 number showing a 
positive effect on Return on Assets that is decreased over several periods. This is not up to the standards.

\subsection{Partial test (t test)}

Table 9. T-Test Results

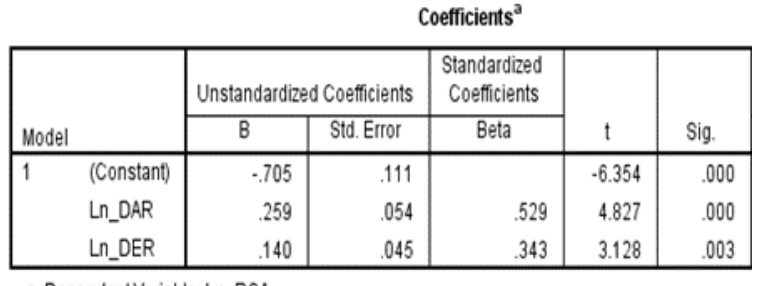

a. DependentVariable: Ln_ROA

The above linear regression equation shows (1) that if the number -0.705 , i.e. the equity debt and the equity indebtedness ratio equals (0), the equity rate is -0.705 . The results of this linear regression test show that a fall in the Return on Assets value results in a value that does not conform to the standard. (2) $\beta 1$ or debt to asset ratios of 0.259 which show a positive effect of return on assets and increase to 0.259 . The results of the linear regression analysis referred to above can also be interpreted to suggest that the debt to asset ratio is increased and exceeds the standard compared to the declining results of the asset return test. This helps to make the variable $\mathrm{X} 1$ positive for variable $\mathrm{Y}$, which can be caused by default (default), as the company finances too much debt assets. (3) $\beta 2$ or the equity debt ratio produces a value which continues to rise over a number of periods, which results in a number 0.140 which exhibits a positive effect of multi-phase Return on Assets. This is not in line with the standards.

\subsection{Discussion of data analysis results (hypothesis proof)}

\subsubsection{Effect of debt to asset ratio (DAR) on return on assets (ROA)}

The first assumption is whether the debt-to-asset ratio (DAR) impacts on returns on assets (ROA). The table of Table 4.12 is 4,827 and the table of Table 2.00575. The significance value is 0.000 , so that there is a positive and significant impact on the return on assets variable Debt to Asset Ratio (DAR) (ROA). According to its results, the higher the value of a debt-to-asset ratio, the greater the financial risk, the greater this ratio indicates that the higher the cost to fulfill its obligations that must be borne by the company, according to Horne \& Wachowisz's [6]. This can be caused by default, because the company has committed too much debt assets. With a risk of default, the higher the cost of a company, the lower the debt to asset ratio, the higher the ability of the company to overcome the corporate debt.

The results of this study are consistent with the current ratio, debt to asset relationship, total capital turnover and inflation on returns on assets [18]. The result of this study is also in accordance with [1], who examined whether the debt-to-asset ratio and debt-to-equity ratio have an important impact in the return on assets.

The results of this research are inversely proportional to those investigated by Widiyanti and Elfina [9], which states that the greater the debt-to-asset ratio, the greater the financial risk, according to Horne \& Wachowisz [6]. The risks in question are increased because the company 
finances too many debt assets. The larger this ratio indicates, based on Pecking Order Theory, that the higher the costs the company will have to bear in fulfilling its obligations. This can reduce the company's profitability (ROA). The higher this ratio the higher the amount of lending capital used to invest in assets to generate company profits. A high ratio is an increase in the creditor risk in the form of the failure of the company to pay all its obligations. The shareholders' side will have a high ratio that will eventually reduce dividend payments. Then there is a negative influence between DAR and ROA.

According to Pebrianti [12], the results of regression tests to test the ROA effect of the independent DAR and DER variables have been found to have an irrelevant effect on the ROA variable of the LQ 45 index companies listed on the Indonesian Börse. The DAR variable is 0.233 ) and the DER variable is -1.362 based on the data processing results, which means the regression is not significant. Afrinda [11] states that the debt-to-total asset ratio on ROA has a negative and significant impact. The negative effect of the debt, the debt ratio to the return of assets, is insignificant; according to Kamal [7] the reduced debt to asset ratio can be due to decreased total debt and ineffective processing of activa. Profit was not maximized to decrease net income, too.

The debt-to-asset ratio is the ratio of total debt to total assets, according to Samsul [10]. Total debt covers short-term and long-term debt. Current assets plus fixed assets and other assets are included in the total assets. Debt to asset ratio indicates at a time the amount of debt to total assets. The position of this ratio can change for better or for worse every month or every year.

\subsubsection{Effect of debt to equity ratio (DER) on return on assets (ROA)}

The second hypothesis is whether the debt-to-equity ratio influences the return on assets derived from Table 4.12 with a tcount of 2,120 and a table value of 2,00958. The value is 0.039 . This means that the Debt to Equity Ratio (DER) variable on return on assets has a negative and significant impact (ROA). With this study, the debt to equity ratio has a connection with the return on assets, which can lead to a decrease of return on assets if the debt to equity ratio increases. This is because total capital increases are higher than total assets and the value of Return On Assets may be reduced.

The results of this study are consistent with the current ratio, debt to asset relationship, total capital turnover and inflation on returns on assets [18]. The results of this study are also consistent with [1] who examined the effect on return on assets of debt to equity and of debt to equity ratios. which states that the debt to equity ratio affects Return on Assets in a significant way. According to Soesetio [14], it affects the dividend payout ratio simultaneously.

Widiyanti and Elfina [9] studied the results of research that are inversely proportional, stating. Taking the newspaper, the DER level will affect the company's level of ROA achievement. If debt costs are lower than equity, the source of the funds from the fund source or debt will be more efficient in profit generation (increasing return on assets) and vice versa [2]. On the basis of the theory of pecking orders, companies with increasing profit are offered profitable opportunities to finance their investments internally so that companies do not attract foreign funds and try to find the right solution to debt problems. Debt affects the performance of companies badly, as the higher the debt level, the higher the interest cost and thus the lower profit. The higher the DER, the greater the burden on foreigners, the more likely it will be to decrease the performance of the company. The effect from DER to ROA is negative. According to Pebrianti [12] the results of regression tests to test the ROA effect of the independent DAR and DER variables have been found to have an irrelevant effect on the ROA variable of the LQ 45 index companies listed on the Indonesian Börse. The DAR variable is -0.233) and the DER 
variable is -1.362 based on the data processing results, which means the regression is not significant. Afrinda [11] says that DER has a significant and negative impact on the ROA. According to Rini et al. [13], the debt ratio in the consumables sector by companies has no significant impact on the value of the firm as reflected in the book price to value, which is why the third hypothesis is rejected. Jamil (2015) said they have no significant effect in this research, according to Muhammadinah and Mahmud. The Debt to Equity Ratio (DER) is a ratio of total debt to equity, according to Samsul [10]. The position ratio can change for better or worse every month or every year.

\subsubsection{Effect of debt to asset ratio (DAR) and debt to equity ratio (DER) on return on assets (ROA)}

Based on research findings at the same time (Test F), it is known that the DAR and DER (Debt to Equity Ratio) together influence the returns on assets (ROA). This can be seen from the importance value of the 0.000 or $<0.05$ ANOVA table. The results of this study show that the higher the value of the debt to the equity ratio, and the lower the return on assets that is not compliant with the standard.

The results are in line with Supardi \& Suratno [18] and Akbar [1] indicating an important impact on the Return on Assets in debt to assets and debt to equity ratio.

Research results are inversely proportional to Widiyanti and Elfina's [9], which shows that Debt to Asset Ratio (DAR), Debt to Equity Ratio (DER) and Long Term Debt to Simultaneously show no significant impact on Automotive and Component Sub-sector Component (ROA) Equity Ratio (LDER). According to Pebrianti [12], the results of regression tests to test the ROA effect of the independent DAR and DER variables have been found to have an irrelevant effect on the ROA variable of the LQ 45 index companies listed on the Indonesian Börse. The DAR variable is -0.233 ) and the DER variable is -1.362 based on the data processing results, which means the regression is not significant. According to Afrinda [11] there is a negative impact on return on assets by the variables Debt in Asset Ratio and Debt in Equity Ratio. The negative effect is not significant according to Kamal [7] not maximum to decrease net profit also.

\section{Conclusion}

Based on test results from the above data on the effect of the debt-to-account ratio (DAR) and debt-to-equity ratio (DER) on asset returns (ROA) in food and drink manufacturing subsectors listed for the 2012-2018 Southeast Asian stock exchange, the researchers draw the following conclusions. The t-assessment of the debt to asset ratio (DAR) (X1) variable has a significant $0,000<0.05$ level, which means that it partially states that the Debt to Asset Ratio (DAR) variable has a negative but significant influence on the return on assets (ROA). The ttest of the variable ratio of debt to equity (DER) (X2), which is significantly $0.003<0.05$, which is that the Debt-to Equity Ratio (DER) variable has a negative and significant effect on return on assets (ROA). The Debt to Asset Rate and Debt to Equity Ratio variable f-test test has a simultaneous effect on asset return, with a significant $0,000<0.05$ level. 


\section{References}

[1] Akbar, S., Studi Manajemen, P., \& Ekonomi dan Bisnis, F. (n.d.). Prosiding Manajemen Pengaruh Debt To Asset Ratio dan Debt To Equity Ratio terhadap Return On Asset (Studi pada Perusahaan Sektor Food \& Beverages yang terdaftar di Bursa Efek Indonesia) Effect of Debt To Asset Ratio and Debt To Equity Ratio on Return On Asset (Study On Food \& Beverages Sector Companies Listed on Indonesia Stock Exchange).

[2] Brigham, Eugene F. ; Houston, Joel F. ; Yulianto, Ali Akbar.Dasar-Dasar Manajemen Keuangan : Fundamentals Of Financial Management (buku 2) / Eugene F. Brigham, Joel F. Houston, Ali Akbar Yulianto .2006

[3] Dan, M., Alfan, M., Fakultas, J., Dan, E., \& Islam, B. (2015). KONSUMSI YANG TERDAFTAR DI BURSA EFEK INDONESIA. In I-Economics Journal (Vol. 1, Issue 1).

[4] Fahmi, Irham. 2016. Pengantar Manajemen Keuangan. Edisi Ke-5. Bndung: Alfabeta

[5] Imam gozali. (2013). Aplikasi Analisis Multivate (9th ed.). Undip Semarang.

[6] James C. Van Horne \& John M. Wachowicz jr. 2009. Prinsip-prinsip Manajemen Keuangan. Jakarta : Salemba Empat.

[7] Kamal, Basri, M. 2018. "Pengaruh Receivable Turn Over dan Debt to Asset Ratio (DAR) Terhadap Return On Asset (ROA) Pada Perusahaan Pertanian yang Terdaftar di Bursa Efek Indonesia.” Jurnal Ilmiah Manajemen dan Bisnis Vol. 17, No. 02, Oktober1693-7619 (Print).

[8] Kasmir. (2018). ANALISIS LAPORAN KEUANGAN (11th ed.). PT. Raja Grafindo Persada.

[9] Manajemen, J., Bisnis, D., Vol, S., Widiyanti, M., \& Dwi Elfina, F. (n.d.). Marlina Widiyanti dan Friska Dwi Elfina PENGARUH FINANCIAL LEVERAGE TERHADAP PROFITABILITAS PADA PERUSAHAAN SUB SEKTOR OTOMOTIF DAN KOMPONEN YANG TERDAFTAR DI BURSA EFEK INDONESIA.

[10] Mohamad Samsul. (2015). PASAR MODAL DAN MANAJEMEN PORTOFOLIO (2nd ed.). Erlangga.

[11] Nidya Afrinda. (2018). “ANALISIS PENGARUH LIKUIDITAS DAN SOLVABILITAS TERHADAP PROFITABILITAS PADA PERUSAHAAN MAKANAN DAN MINUMAN YANG TERDAFTAR DI BURSA EFEK INDONESIA.”

[12] Pebrianti, Y., Negeri, P., \& Id, S. Y. C. (n.d.). INDEKS LQ 45 BURSA EFEK INDONESIA.

[13] Setia Rini, R., Puspitaningtyas, Z., \& Prakoso, A. (2018). PENGARUH CURRENT RATIO, TOTAL ASSET TURNOVER DAN DEBT TO EQUITY RATIO TERHADAP PRICE TO BOOK VALUE DENGAN RETURN ON ASSET SEBAGAI VARIABEL INTERVENING (Studi Pada Perusahaan Sektor Industri Barang Konsumsi di Bursa Efek Indonesia Periode 2013-2017). Jurnal Profita, 11(3), 329-358. https://doi.org/10.22441/profita.2018.v11.03.001

[14] Soesetio, Yuli. 2008. "Pengaruh Perubahan Return On Asset, Perubahan Debt to Equity Ratio Perubahan Cash Ratio Terhadap Perubahan Deviden Payout Ratio". MODERNISASI, Volume 4, Nomor 1, Februari 2008.

[15] Sugiyono. 2010. Metode Penelitian Pendidikan Pendekatan Kuantitatif, kualitatif, dan R\&D. Bandung: Alfabeta

[16] (2014). Metode Penelitian Pendidikan Pendekatan Kuantitatif, Kualitatif, dan R\&D. Bandung: Alfabeta.

[17] 2017. Metode Penelitian Bisnis. Edisi ke-3. Bandung: Alfabeta

[18] Supardi, H., \& Suratno, H. (2016). PENGARUH CURRENT RATIO, DEBT TO ASSET RATIO, TOTAL ASSET TURNOVER DAN INFLASI TERHADAP RETURN ON ASSET. Jurnal Ilmiah Akuntansi Fakultas Ekonomi, 2(Tahun), 16-27.

[19] Zulkarnaen, Zuliana. 2018. "Pengaruh Debt to Assets Ratio (DAR) Terhadap Return On Asset (ROA) Pada Perusahaan Asuransi Yang Terdaftar di BEI Tahun 2010-2015. Jurnal Warta Edisi : 56 April 2018 | ISSN : 1829 - 7463.“ 